\title{
WETENSCHAP
}

\section{De beursgenoteerde vennootschap}

\section{Faits divers}

C. de Groot

\section{Inleiding}

In Boek 2 van het Burgerlijk Wetboek (BW) komt de term 'beursgenoteerde' naamloze vennootschap (nv) of besloten vennootschap (bv) niet voor. Boek 2 BW spreekt over een vennootschap waarvan aandelen (of certificaten van aandelen) ${ }^{1}$ zijn toegelaten tot de handel op een gereglementeerde markt (RM, regulated market) en soms ook een multilaterale handelsfaciliteit (MTF, multilateral trading facility). Hierna volgen enkele verspreide opmerkingen over de beursgenoteerde vennootschap. Paragraaf 2 gaat over (het verschil tussen) de RM en de MTF en hoe beide terugkomen in Boek 2 BW en in de Wet op het financieel toezicht (Wft). Daarna komen twee recente regelingen aan bod. Paragraaf 3 gaat in op de regeling van de wettelijke bedenktijd die voor beursgenoteerde vennootschappen op 1 mei 2021 in werking is getreden. Paragraaf 4 gaat over het wetsvoorstel dat onder meer een $\mathrm{m} / \mathrm{v}$-quotum introduceert voor beursgenoteerde vennootschappen. In paragraaf 5 staan een korte conclusie en enkele kanttekeningen bij de wettelijke bedenktijd en het voorgestelde $\mathrm{m} / \mathrm{v}$-quotum.

\section{Gereglementeerde markt en multilaterale handelsfaciliteit}

De regelgeving over een $\mathrm{RM}$ en een MTF is in belangrijke mate gebaseerd op de MiFID II-richtlijn (de afkorting MiFID staat voor Markets in Financial Instruments Directive). ${ }^{2}$ Zowel een RM als een MTF is, in de terminologie van de MiFID II-richtlijn, een 'handelsplatform'. ${ }^{3}$ De richtlijn maakt een onderscheid tussen RM's en MFT's door in het kader van MFT's te spreken over 'op kleinere en middelgrote emittenten toegesneden markten'. ${ }^{4}$ Handelsplatformen worden in stand gehouden

1 Hierna zal alleen nog over aandelen worden gesproken.

2 Richtlijn 2014/65/EU van het Europees Parlement en de Raad van 15 mei 2014 betreffende markten voor financiële instrumenten en tot wijziging van Richtlijn 2002/92/EG en Richtlijn 2011/61/ EU (herschikking) (voor de EER relevante tekst), PbEU 2014, L 173/349.

3 MiFID II-richtlijn, preambule onder 14; vgl. art. 1 lid 1 onder 24.

4 MiFID II-richtlijn, preambule onder 134; vgl. S. Rosmalen, Multilaterale handelsfaciliteiten en dark pools. Is MiFID na drie jaar al aan herziening toe?, O\&F 2010, afl. 4, p. 29-45; F.M. Schlingman, Markttoegang, in: J.B. Huizink \& D. Schoenmaker (red.), Leerboek Wft, Apeldoorn/Antwerpen: Maklu 2009, p. 109-133 (p. 117): 'een soort alternatieve beurs geïntroduceerd door MiFID ter vergroting van de concurrentie met de traditionele effectenbeurzen'. 
door een 'exploitant'. ${ }^{5}$ De exploitant van een RM is een 'marktexploitant' (art. 4 lid 1 onder 18 en 21). De exploitant van een MFT is meestal een 'beleggingsonderneming' (art. 4 lid 1 onder 21). ${ }^{6}$ Zowel een RM als een MFT is een 'multilateraal systeem'; de richtlijn omschrijft een multilateraal systeem als een systeem waarin 'koop- en verkoopintenties van derden met betrekking tot financiële instrumenten op elkaar kunnen inwerken' (art. 4 lid 1 onder 19). In beide gevallen gebeurt dat volgens 'niet-discretionaire regels' (art. 4 lid 1 onder 21 en 22). Multilateraal houdt in dat het systeem de koop- en verkoopintenties van alle cliënten doorlopend bij elkaar brengt (en dus niet in incidentele gevallen matcht); niet-discretionair houdt in dat het systeem werkt op basis van vooraf vastgestelde regels (en dus niet van die regels mag afwijken). ${ }^{7}$

Een RM is geregeld in afdeling 5.2.2 van de Wft: 'Het exploiteren of beheren van een gereglementeerde markt'. Art. 5:26 lid 1 Wft bepaalt dat voor het exploiteren van een RM een vergunning is vereist van de Minister van Financiën.

Om als beleggingsonderneming werkzaam te mogen zijn, is eveneens een vergunning nodig; die vergunning wordt verleend door de Autoriteit Financiële Markten (art. 2:96 lid $1 \mathrm{Wft}$ ). Een MFT is geregeld in paragraaf 4.3.7.2 van de Wft: 'Exploiteren van een georganiseerde handelsfaciliteit of een multilaterale handelsfaciliteit'. ${ }^{8}$

De regels die gelden voor het exploiteren van een RM en van een MTF zijn niet identiek, maar vertonen (logischerwijze) wel overeenkomsten. Dat komt naar voren in art. 5:30 en 4:91a Wft (zie tabel 1).

5 MiFID II-richtlijn, preambule onder 14.

6 Ook een marktexploitant kan een MFT exploiteren.

7 Vgl. F.K. Buijn \& P.M. Storm, Ondernemingsrecht BV en NV in de praktijk, Deventer: Kluwer 2013, p. 625; G.T.J. Hoff, Openbaarmaking van koersgevoelige informatie, Deventer: Kluwer 2011, par. 4.4.7 'Intermezzo; zoek de verschillen tussen een gereglementeerde markt en een multilaterale handelsfaciliteit'; F.F. Nagelkerke \& E.J.H. Vis-Osendarp, Multilaterale handelsfaciliteit (MTF), in: D. Busch \& C.M. Grundmann-van de Krol (red.), Handboek beleggingsondernemingen. Deel I, Deventer: Wolters Kluwer 2019, par. 18.2.3.

8 De eerste bepaling van deze paragraaf, art. 4:91.0a luidt: 'Deze paragraaf is van overeenkomstige toepassing op een marktexploitant die een (...) multilaterale handelsfaciliteit exploiteert.' De vergunning van de marktexploitant is dan de vergunning op basis van art. 5:26 lid $1 \mathrm{Wft}$, waarbij de marktexploitant gebruik kan maken van art. 2:96 lid 2 Wft: 'De Autoriteit Financiële Markten kan op aanvraag geheel of gedeeltelijk, al dan niet voor bepaalde tijd, ontheffing verlenen van het eerste lid indien de aanvrager aantoont dat de belangen die dit deel, het Deel Prudentieel toezicht financiële ondernemingen en het Deel Gedragstoezicht financiële ondernemingen beogen te beschermen anderszins voldoende worden beschermd.' 


\section{Tabel 1 Regels voor het exploiteren van een $R M$ en een $M T F$}

\begin{tabular}{|c|c|}
\hline Art. 5:30 Wft: RM & Art. 4:9I a Wft: MTF \\
\hline Een marktexploitant moet onder meer: & Een beleggingsonderneming moet onder meer: \\
\hline $\begin{array}{l}\text { - } \quad \text { beschikken over regels en procedures op } \\
\text { het gebied van belangenconflicten tussen } \\
\text { de RM en de marktexploitant als die } \\
\text { belangenconflicten negatieve gevolgen } \\
\text { kunnen hebben voor de exploitatie of de } \\
\text { goede werking van de gereglementeerde } \\
\text { markt of voor haar deelnemers (lid I } \\
\text { onder a) }\end{array}$ & $\begin{array}{l}\text { - } \quad \text { transparante regels en procedures } \\
\text { vaststellen die een billijke en ordelijke } \\
\text { handel garanderen (lid I) }\end{array}$ \\
\hline $\begin{array}{l}\text { - beschikken over regels en procedures } \\
\text { voor een gezond beheer van de } \\
\text { technische werking van het systeem en } \\
\text { voor voorzorgsmaatregelen om de risico's } \\
\text { van systeemstoringen te ondervangen } \\
\text { (lid I onder c) }\end{array}$ & $\begin{array}{l}\text { - } \quad \text { regels en procedures vaststellen voor een } \\
\text { gezond beheer van de technische werking } \\
\text { van het systeem en voorzorgsmaatregelen } \\
\text { om de risico's van systeemverstoringen te } \\
\text { ondervangen (lid 2) }\end{array}$ \\
\hline $\begin{array}{l}\text { - beschikken over transparante, niet-discre- } \\
\text { tionaire regels en procedures voor een } \\
\text { billijke en ordentelijke handel en } \\
\text { objectieve criteria voor de uitvoering van } \\
\text { orders (lid I onder d) })^{\mathrm{a}}\end{array}$ & $\begin{array}{l}\text { - transparante regels vaststellen aan de } \\
\text { hand waarvan wordt vastgesteld welke } \\
\text { financiële instrumenten via het systeem } \\
\text { kunnen worden verhandeld (lid 3), en } \\
\text { transparante en niet-discriminerende } \\
\text { regels vaststellen voor toegang tot de MFT } \\
(\text { lid 5) }\end{array}$ \\
\hline $\begin{array}{l}\text { - beschikken over regels en procedures } \\
\text { voor een doelmatige en tijdige afhandeling } \\
\text { van via haar systemen uitgevoerde } \\
\text { transacties (lid I onder e) }\end{array}$ & \\
\hline $\begin{array}{l}\text { - beschikken over voldoende financiële } \\
\text { middelen om een ordelijke werking van } \\
\text { de markt te bevorderen (gelet op de aard } \\
\text { en omvang van de op de markt uitgevoer- } \\
\text { de transacties en de aard en omvang van } \\
\text { de risico's waaraan zij is blootgesteld) } \\
\text { (lid I onder } \mathrm{f} \text { ) }\end{array}$ & $\begin{array}{l}\text { - zorgen voor publieke informatie zodat de } \\
\text { gebruikers van haar handelsfaciliteit zich } \\
\text { een beleggingsoordeel kunnen vormen } \\
\text { (rekening houdend met zowel de aard } \\
\text { van de gebruikers als de categorieën } \\
\text { verhandelde financiële instrumenten) } \\
\text { (lid 4) }\end{array}$ \\
\hline
\end{tabular}

a. Dat de regels en procedures niet-discretionair moeten zijn, volgt ook uit de omschrijving van een gereglementeerde markt in art. I:I Wft: een 'multilateraal systeem dat meerdere koop- en verkoopintenties van derden met betrekking tot financiële instrumenten - binnen dit systeem en volgens de niet-discretionaire regels van dit systeem - samenbrengt (...)'.

b. Dat de handel ook volgens niet-discretionaire regels moet plaatsvinden, volgt uit de omschrijving van een MFT in art. I:I Wft: 'een multilateraal systeem dat meerdere koop- en verkoopintenties van derden met betrekking tot financiële instrumenten, binnen dit systeem en volgens de niet-discretionaire regels, samenbrengt (...)'.

Vermeldenswaardig is dat hoofdstuk 5.3 van de Wft ('Regels voor het melden van stemmen, kapitaal, zeggenschap en kapitaalbelang in uitgevende instellingen') alleen van toepassing is op uitgevende instellingen met een beursnotering aan een RM (vergelijk onder meer art. 5:33 lid 1 onder a Wft). Datzelfde geldt voor hoofdstuk 5.5 van de Wft ('Openbaar bod op effecten'; vergelijk onder meer art. 5:70 lid $1 \mathrm{Wft}$ ), en de daarmee samenhangende art. 2:359a tot en met 2:359d BW over 'Het openbaar bod'.

De regels in hoofdstuk 5.6a van de Wft ('Transparantieregels ter bevordering van langetermijnbetrokkenheid aandeelhouders') beperken zich tot RM's (vergelijk 
art. 5:87a Wft), terwijl de regels in hoofdstuk 5.6 van de Wft ('Regels over het toepassen van een gedragscode door institutionele beleggers') zowel betrekking hebben op beleggingen die plaatsvinden op een RM als op een MTF (vergelijk art. 5:86 lid $1 \mathrm{Wft}$ ).

Verder zijn in Boek 2 BW art. 2:135a en 2:135b BW over het bezoldigingsbeleid voor bestuurders van beurgenoteerde vennootschappen en de bepalingen over 'Transacties met verbonden partijen' (art. 2:167 t/m 2:170 BW) alleen van toepassing op vennootschappen waarvan aandelen zijn toegelaten tot de handel op een RM. Art. 2:132 lid 3 BW, dat bepaalt dat de rechtsverhouding tussen een bestuurder en een beursgenoteerde vennootschap niet wordt aangemerkt als een arbeidsovereenkomst, is daarentegen zowel van toepassing op beursvennootschappen met een notering aan een RM als aan een MTF.

Opvallend is dat hoofdstuk 5.6 van de Wft en art. 2:132 lid 3 BW (die zich ook op MTF's richten) in tegenstelling tot de andere regelingen geen Europeesrechtelijke achtergrond hebben. De Europeesrechtelijke regels over beursgenoteerde vennootschappen beperken zich tot vennootschappen waarvan aandelen zijn toegelaten tot de handel op een RM. De Nederlandse wetgever gaat, wanneer het om regelingen gaat die geen Europeesrechtelijke achtergrond hebben, dus een stapje verder door ook beursgenoteerde vennootschappen met een MTF-notering 'mee te nemen'.

De verschillende bepalingen in Boek 2 BW waarin wordt gesproken over een RM of een MTF verwijzen naar een RM of een MTF zoals bedoeld in de Wft. Omdat de omschrijvingen van een RM en een MTF in de Wft zijn gebaseerd op Europese regelgeving, gaat het daarmee om RM's en MTF's in de zin van die Europese regelgeving, met name de MiFID II-richtlijn. Dat zijn dus RM's en MTF's die in de Europese Unie opereren, ${ }^{9}$ en (in de kop boven de MiFID II-richtlijn staat de aanduiding 'Voor de EER relevante tekst') ook RM's en MTF's die in de andere EER-landen opereren (IJsland, Liechtenstein en Noorwegen). Een vennootschap waarvan aandelen alleen zijn toegelaten tot de handel op een RM of een MTF buiten de EU/EER (en niet tevens tot de handel op een RM of een MTF binnen de EU/EER) valt buiten het bereik van die bepalingen. Hoofdstuk 5.6 van de Wft en art. 2:132 lid 3 BW gaan ook op dit punt verder. Deze regelingen, die geen Europeesrechtelijke achtergrond hebben, zijn niet alleen van toepassing op beursvennootschappen met een notering aan een RM of een MTF in de EU/EER, maar richten zich ook op beursnotering aan 'een met een gereglementeerde markt of multilaterale handelsfaciliteit vergelijkbaar systeem uit een staat die geen lidstaat is', dat wil zeggen buiten de EU/ EER. ${ }^{10}$

9 Dus inmiddels zonder het Verenigd Koninkrijk.

10 Vgl. de definitie van 'lidstaat' in art. 1:1 Wft: 'een staat die lid is van de Europese Unie alsmede een staat, niet zijnde een lidstaat van de Europese Unie, die partij is bij de Overeenkomst betreffende de Europese Economische Ruimte'. 


\section{$3 \quad$ Wettelijke bedenktijd}

Op 1 mei 2021 is de Wet van 24 maart 2021 tot wijziging van Boek 2 van het Burgerlijk Wetboek in verband met het inroepen van een bedenktijd door het bestuur van een beursvennootschap in werking getreden. ${ }^{11}$ Deze wet geeft het bestuur van een beursgenoteerde vennootschap de mogelijkheid de besluitvorming in de algemene vergadering over (kort gezegd) benoeming, schorsing en ontslag van bestuurders en/of commissarissen in drie gevallen (waaronder het geval dat een openbaar bod is aangekondigd of uitgebracht op de aandelen in het kapitaal van de vennootschap zonder dat de bieder en de vennootschap daarover overeenstemming hebben bereikt) voor maximaal 250 dagen on hold te zetten. Hiermee creëert het bestuur tijd om voor zichzelf te komen tot (wat de wet noemt) 'een zorgvuldige beleidsbepaling'. Deze bedenktijd wordt wel aangeduid als de 'wettelijke' bedenktijd, omdat deze bedenktijd lijkt op de responstijd in de Nederlandse Corporate Governance Code. De bedenktijd staat in art. 2:114b BW; de responstijd staat in best practice bepaling 4.1.6 en 4.1.7. ${ }^{12}$ De wettelijke regeling van de bedenktijd bevat (naast art. 2:114b BW) nog een element. De regeling voegt aan de bestaande tekst van art. 2:129 BW ('Behoudens beperkingen volgens de statuten is het bestuur belast met het besturen van de vennootschap') een tweede volzin toe. Gaat het over de bestuurstaak van een beursgenoteerde vennootschap, dan 'is daaronder in ieder geval begrepen het bepalen van het beleid en de strategie van de vennootschap'. ${ }^{13}$

De reikwijdte van de regeling van de bedenktijd, die geen Europeesrechtelijke achtergrond heeft, is buitengewoon ruim. Art. 2:114b lid 1 BW spreekt over vennoot-

11 Stb. 2021, 185, Kamerstukken 35367; Besluit van 20 april 2021 tot vaststelling van het tijdstip van inwerkingtreding van de Wet van 24 maart 2021 tot wijziging van Boek 2 van het Burgerlijk Wetboek in verband met het inroepen van een bedenktijd door het bestuur van een beursvennootschap (Stb. 2021, 185), Stb. 2021, 210. Vgl. C.J.C. de Brauw, Nut en noodzaak van de wettelijke bedenktijd bij strategiebepaling en het bestaande raamwerk van beschermingsmogelijkheden, Ondernemingsrecht 2020/52; A. Duldar \& E.C.H.J. Lokin, De wettelijke bedenktijd: ter achtergrond, MvO 2019, afl. 5/6, p. 137-140; L.F. Groothuis, Toepassing van de wettelijke bedenktijd in de (proces)praktijk, Ondernemingsrecht 2020/53; A.J.J.P.B.M. Kersten, Voorontwerp bedenktijd: een bedenkelijke geringschatting van het ondernemingsrecht, $\mathrm{MvO}$ 2019, afl. 5/6, p. 145-148; R.H. Kleipool \& R.L. Pouwe, Tijd en rust wettelijk toegevoegd aan de gereedschapskist van het bestuur, MvO 2019, afl. 5/6, p. 141-144; H. Koster, Het wetsvoorstel wettelijke bedenktijd beursvennootschappen onderzocht, O\&F 2020, afl. 3, p. 74-88; N.D. Niederer, De wettelijke bedenktijd in het licht van een goede corporate governance, $\mathrm{MvO}$ 2020, afl. 10/11, p. 318-324; M. van Olffen, Voorontwerp wettelijke bedenktijd beursvennootschappen, Ondernemingsrecht 2019/12; M. van Olffen, Wetsvoorstel wettelijke bedenktijd beursvennootschappen, Ondernemingsrecht 2020/51; W.J. Oostwouder \& R.P. Schrooten, Wettelijke bedenktijd en beschermingsconstructies, de wereld op zijn kop!, O\&F 2018, afl. 3, p. 33-56; R. Traas, De voorgestelde wettelijke bedenktijd: een (on)gerechtvaardigde belemmering?, MvO 2019, afl. 5/6, p. 149-154.

12 Vgl. Kamerstukken II 2020/21, 35367, nr. 3, p. 13 (MvT): 'De termijn van 250 dagen is langer dan de responstijd in de Code van 180 dagen om het bestuur voldoende tijd en rust te geven voor een zorgvuldige beleidsbepaling.'

13 Vgl. Kamerstukken II 2020/21, 35367, nr. 3, p. 10 (MvT): 'Het primaat van het bestuur ten aanzien van de strategie wordt in de wet geëxpliciteerd. Codificatie van de jurisprudentie op dit punt wordt wenselijk geacht, ook om de kenbaarheid hiervan - met name voor Angelsaksisch georiënteerde aandeelhouders - te vergroten.' 
schappen waarvan aandelen zijn toegelaten 'tot de handel op een gereglementeerde markt of een multilaterale handelsfaciliteit als bedoeld in artikel 1:1 van de Wet op het financieel toezicht of een met een gereglementeerde markt of multilaterale handelsfaciliteit vergelijkbaar systeem uit een staat die geen lidstaat is'. Hierover schrijft de memorie van toelichting: 'Voor deze ruime reikwijdte is gekozen, omdat het voor de toepassing van regels inzake de bevoegdheden van organen in Nederlandse vennootschappen niet relevant wordt geacht op welke beurs de aandelen zijn genoteerd. ${ }^{14}$ Dit is dezelfde reikwijdte als die van hoofdstuk 5.6 van de Wft en art. 2:132 lid 3 BW.

Het bestuur van een beursgenoteerde vennootschap kan de bedenktijd in drie gevallen inroepen, maar moet het inzetten van de bedenktijd wel afwegen.

Als eerste in het geval dat een of meer aandeelhouders gebruik maken van art. 2:114a BW: het agenderingsrecht (art. 2:114b lid 2 onder a BW). Op basis van art. 2:114a BW wordt de vennootschap geacht een onderwerp op de agenda van de algemene vergadering te plaatsen wanneer een of meer aandeelhouders die ten minste $3 \%$ van het geplaatste kapitaal vertegenwoordigen dat schriftelijk, gemotiveerd en tijdig (op zijn laatst zestig dagen voor de geplande algemene vergadering) verzoeken. De bedenktijd sluit aan bij art. 2:114a BW en heeft in dit geval betrekking op twee typen agenderingsverzoeken. Het eerste type zijn agenderingsverzoeken tot plaatsing van een agendapunt met een voorstel tot benoeming, schorsing of ontslag van een of meer bestuurders of commissarissen. Het tweede type zijn agenderingsverzoeken tot plaatsing van een agendapunt met een voorstel tot wijziging van een statutaire bepaling over benoeming, schorsing of ontslag van bestuurders of commissarissen.

Als tweede in het geval dat een of meer aandeelhouders gebruik maken van art. 2:110 en 2:111 BW: het bijeenroepingsrecht (art. 2:114b lid 2 onder a BW). Op basis van art. 2:110 BW kan de voorzieningenrechter een of meer aandeelhouders die ten minste $10 \%$ van het geplaatste kapitaal verschaffen op hun verzoek machtigen zelf een algemene vergadering bijeen te roepen. ${ }^{15}$ Dat kan indien die aandeelhouders het bestuur en de raad van commissarissen schriftelijk en met opgave van de te behandelen onderwerpen hebben gevraagd zo'n vergadering bijeen te roepen, en noch het bestuur, noch de raad van commissarissen daartoe is overgegaan. De wijze van toetsing door de voorzieningenrechter van een bijeenroepingsverzoek staat in art. 2:111 BW. De voorzieningenrechter wijst het verzoek van de aandeelhouders toe als 'zij een redelijk belang hebben bij het houden van de vergadering'. De bedenktijd sluit aan bij art. 2:110 BW en heeft ook in dit geval betrekking op twee typen bijeenroepingsverzoeken. Het eerste type zijn bijeenroepingsverzoeken van een algemene vergadering met als agendapunt een voorstel tot benoeming, schorsing of ontslag van een of meer bestuurders of commissarissen. Het tweede type zijn bijeenroepingsverzoeken van een algemene vergadering met als agendapunt een voorstel tot wijziging van een statutaire bepaling over benoeming, schorsing of ontslag van bestuurders of commissarissen. vennootschap, Deventer: Kluwer 2013/206, die speekt over 'geautoriseerde bijeenroeping'. 
Als derde in het geval dat een openbaar bod is aangekondigd of is uitgebracht op de aandelen in het kapitaal van de vennootschap, terwijl de bieder en de vennootschap over dat bod geen overeenstemming hebben bereikt (art. 2:114b lid 2 onder b BW).

De afweging die het bestuur moet maken, is volgens art. 2:114b lid 2 BW of het agenderingsverzoek, het bijeenroepingsverzoek of het openbaar overnamebod 'naar het oordeel van het bestuur wezenlijk in strijd is met het belang van de vennootschap en de met haar verbonden onderneming'.

Het bestuur kan de bedenktijd inroepen voor maximaal 250 dagen (art. 2:114b lid 5 BW). Het bestuur kan de bedenktijd altijd beëindigen (art. 2:114b lid 5 BW). De raad van commissarissen moet het besluit van het bestuur tot het inroepen van de bedenktijd goedkeuren (art. 2:114b lid 3 BW). Dat geldt ook voor een besluit van het bestuur tot beëindiging van de bedenktijd (art. 2:114b lid 5 BW).

De gevolgen van het inroepen van de bedenktijd worden (pas) in art. 2:114b lid 6 tot en met 9 BW duidelijk. De algemene vergadering kan tijdens de bedenktijd geen besluiten nemen tot benoeming, schorsing of ontslag van bestuurders of commissarissen en kan statutaire bepalingen die gaan over benoeming, schorsing of ontslag van bestuurders of commissarissen niet wijzigen (tenzij de vennootschap een dergelijk besluit zelf agendeert) (lid 6). Gedurende de bedenktijd moet het bestuur alle informatie verzamelen die het nodig heeft voor 'een zorgvuldige beleidsbepaling' (lid 7). Daartoe moet het bestuur aandeelhouders die ten minste $3 \%$ van het geplaatste kapitaal vertegenwoordigen en de ondernemingsraad consulteren en hun standpunten op de website van de vennootschap plaatsen (tenzij een partij niet wil dat haar standpunt op de website wordt geplaatst). Na afloop van de bedenktijd moet het bestuur een verslag 'van het gevoerde beleid en de gang van zaken sinds het inroepen van de bedenktijd' op de website van de vennootschap plaatsen (lid 8). Dit verslag moet tijdens de eerstvolgende algemene vergadering als bespreekpunt worden geagendeerd (lid 9).

Het inroepen van de bedenktijd verhindert niet dat een bieder een openbaar overnamebod waarover geen overeenstemming is bereikt met de vennootschap doorzet. Dat blijkt ook uit art. 2:114b lid 5 BW, dat bepaalt dat de bedenktijd eindigt op de dag na de gestanddoening van het bod.

Art. 2:114b lid 4 BW geeft (kortweg) aandeelhouders die op het moment van het inroepen van de bedenktijd ten minste $3 \%$ van het geplaatste kapitaal verschaffen de mogelijkheid de Ondernemingskamer te verzoeken de bedenktijd te beëindigen (zoals uitgedrukt in de tekst: 'Een of meer houders van aandelen die bij het inroe- 
pen van de bedenktijd gerechtigd zijn tot agendering ingevolge artikel 114a'). ${ }^{16}$ De Ondernemingskamer wijst dit verzoek toe als het bestuur van de vennootschap op het moment van het inroepen van de bedenktijd niet in redelijkheid kon oordelen dat de bedenktijd in het belang was van de vennootschap en de met haar verbonden onderneming (onder a), als het bestuur inmiddels niet langer in redelijkheid kan oordelen dat de bedenktijd kan bijdragen aan een zorgvuldige beleidsbepaling (onder b), of als de bedenktijd samenvalt met andere (beschermings)maatregelen die met de bedenktijd overeenkomen, en die maatregelen niet na een verzoek van de aandeelhouders die zich tot de Ondernemingskamer hebben gewend binnen een redelijke termijn ongedaan zijn gemaakt (onder c). De c-grond is toegevoegd door een amendement van het Tweede Kamerlid Van Gent. ${ }^{17}$ De toelichting bij het amendement verwijst naar het toenmalige regeerakkoord:

'In het regeerakkoord is opgenomen dat de bedenktijd niet kan worden ingezet "in combinatie met beschermingsconstructies van bedrijven zelf, zoals de uitgifte van preferente aandelen of prioriteitsaandelen". Dit amendement strekt ertoe het wetsvoorstel beter te laten aansluiten bij deze tekst, zodat een onredelijke stapeling van beschermingsmaatregelen wettelijk wordt tegengegaan.'

Als voorbeelden van andere beschermingsmaatregelen noemt de toelichting bij het amendement de mogelijkheid van uitgifte van beschermingspreferente aandelen, certificering van aandelen, de responstijd uit de Nederlandse Corporate Governance Code en prioriteitsaandelen. Als redelijke termijn waarbinnen een maatregel ongedaan moet zijn gemaakt (ook om te voorkomen dat de aandeelhouders zich tot de Ondernemingskamer wenden), spreekt de toelichting over een week.

Art. 2:114b lid 5 BW bevat nog de bepaling dat als het bestuur de bedenktijd heeft ingeroepen in een van de gevallen uit lid 2, het bestuur de mogelijkheid blijft behouden een (nieuwe) bedenktijd in te roepen als zich een ander geval uit lid 2 aandient. Dit is ingevoegd door een amendement van de Tweede Kamerleden Van den Berg en Bruins. ${ }^{18}$ Dit amendement focust op de verhouding tussen enerzijds de twee gevallen in art. 2:114b lid 2 onder a BW en anderzijds het geval in art. 2:114b lid 2 onder b BW. Het amendement probeert te waarborgen dat de gevallen onder a en het geval onder $b$ een eigen bedenktijd krijgen, waarbij een eerdere bedenktijd de latere bedenktijd niet absorbeert. De toelichting bij het amendement gaat in op

16 Kamerstukken II 2020/21, 35367, nr. 14, amendement van het lid Paternotte, 'In artikel I, onderdeel A, wordt in het voorgestelde artikel 114b, lid 4, eerste volzin, "alleen of gezamenlijk tenminste drie honderdste gedeelte van het geplaatste kapitaal vertegenwoordigen" vervangen door "gerechtigd zijn tot agendering ingevolge artikel 114a"', met als toelichting: 'Deze rechtsgang staat in het wetsvoorstel open voor aandeelhouders die ten minste $3 \%$ van het geplaatst kapitaal vertegenwoordigen. Deze $3 \%$ is weliswaar het wettelijk maximum als drempel voor agenderingsrecht, statutair kunnen ondernemingen van dit percentage afwijken', en 'De indiener wil met dit amendement bereiken dat de rechtsgang bij de Ondernemingskamer Amsterdam (OKA) openstaat voor alle aandeelhouders die ook kunnen agenderen in een algemene vergadering van aandeelhouders (AVA).' Kamerstukken II 2020/21, 35367, nr. 15, amendement van het lid Van Gent.

18 Kamerstukken II 2020/21, 35367, nr. 12, amendement van de leden Van den Berg en Bruins. 
de situatie dat een openbaar overnamebod wordt gevolgd door een agenderingsverzoek. Daarover schrijft de toelichting:

'Ter illustratie: als er een vijandig bod wordt uitgebracht, begint de dag erna de 250 dagen bedenktijdtermijn te lopen, ongeacht of de bedenktijd ook daadwerkelijk wordt ingeroepen. Wanneer 100 dagen daarna een agenderingsverzoek wordt ingediend en de bedenktijd nog niet is ingeroepen vanwege het bod, zal voor die situatie een nieuwe termijn moeten gaan lopen. Het is dan niet zo dat die betreffende bedenktermijn ineens wordt ingekort met $100 \mathrm{da}-$ gen, omdat er als gevolg van het bod reeds een termijn was gaan lopen, terwijl de bedenktijd niet was ingeroepen. Uiteraard geldt hetzelfde ook andersom.'

Uit deze passage blijkt tegelijkertijd een opvallend aspect van de bedenktijd. Het bestuur kan de bedenktijd inroepen, maar heeft geen grip op het moment waarop de bedenktijd begint. ${ }^{19}$ Uit art. 2:114b lid 5 BW blijkt dat de begintijd van de bedenktijd als volgt is vormgegeven:

- In het geval van een agenderingsverzoek is dat: 'de dag na de uiterste datum waarop overeenkomstig artikel 114a [zestig dagen; CdG] of de statuten van de vennootschap een verzoek als bedoeld in lid 2 onder a voor de eerstvolgende algemene vergadering moet zijn ontvangen'.

- In het geval van een bijeenroepingsverzoek is dat: 'het moment waarop de voorzieningenrechter de verzochte machtiging heeft verleend'.

- In het geval van een aangekondigd of uitgebracht openbaar overnamebod is dat: 'vanaf uiterlijk de dag na de dag waarop het openbaar bod is uitgebracht'. ${ }^{20}$

Hierbij geldt: 'Indien het bestuur de bedenktijd later inroept, duurt de bedenktijd korter.'21

In het wetsvoorstel stond: 'De bedenktijd geldt voor een termijn van ten hoogste tweehonderdvijftig dagen, gerekend vanaf de dag na de indiening van een verzoek als bedoeld in lid 2 onder a dan wel gerekend vanaf uiterlijk de dag na de dag waarop het openbaar bod is uitgebracht als bedoeld in lid 2 onder b.' Dit is aangepast door een amendement van de Tweede Kamerleden Van den Berg en Paternotte. Dit amendement was ingegeven door de gedachte dat 'indiening' van een verzoek tot agendering een te vroeg moment was, en dat ook in het geval van een bijeenroepingsverzoek een duidelijk moment moest worden bepaald..$^{22}$

19 Vgl. M. van Olffen, Wettelijke bedenktijd beursvennootschappen definitief, Ondernemingsrecht 2021/38, par. 5 'Termijn' over de 'gefixeerde aanvangsdatum'.

20 Vgl. Kamerstukken II 2020/21, 35367, nr. 3, p. 14 (MvT): 'In geval van een vijandig bod kan het bestuur de bedenktijd inroepen vanaf de dag dat het bod wordt aangekondigd. De termijn van 250 dagen begint uiterlijk te lopen vanaf de dag na de dag dat het bod is uitgebracht. Reden hiervoor is dat mogelijk pas bij het biedingsbericht duidelijk is welke bedoeling de bieder met de doelvennootschap en haar stakeholders heeft.'

21 Kamerstukken II 2020/21, 35367, nr. 3, p. 13 (MvT).

22 Kamerstukken II 2020/21, 35367, nr. 18, gewijzigd amendement van de leden Van den Berg en Paternotte ter vervanging van dat gedrukt onder nr. 11 . 


\section{$4 \mathrm{M} / \mathrm{v}$-quotum (en streefcijfer $\mathrm{m} / \mathrm{v}$-verhouding)}

Het wetsvoorstel tot wijziging van Boek 2 van het Burgerlijk Wetboek in verband met het evenwichtiger maken van de verhouding tussen het aantal mannen en vrouwen in het bestuur en de raad van commissarissen van grote naamloze en besloten vennootschappen bevat twee regelingen. ${ }^{23}$ De eerste regeling (art. 2:166 en 2:276 BW) verplicht 'grote' naamloze en besloten vennootschappen 'passende en ambitieuze doelen in de vorm van een streefcijfer vast [te stellen] om de verhouding tussen het aantal mannen en vrouwen in het bestuur en de raad van commissarissen, alsmede bij nader door de vennootschap te bepalen categorieën werknemers in leidinggevende functies, evenwichtiger te maken' (lid 2). De regeling is gericht op vennootschappen die 'groot' zijn in de zin van het jaarrekeningenrecht. Dat zijn niet de entiteiten die worden aangeduid als micro-entiteiten (art. 2:395a BW), kleine entiteiten (art. 2:396 BW) of middelgrote entiteiten (art. 2:397 BW). Het gaat om vennootschappen die volledig jaarrekeningplichtig zijn en die voldoen aan ten minste twee van de volgende drie criteria: de activa zijn volgens de balans meer dan $€ 20$ miljoen; de netto-omzet over het boekjaar is meer dan $€ 40$ miljoen; en het aantal werknemers is meer dan 249 .

De tweede regeling (art. 2:142b BW) bevat (waar toepasselijk in aanvulling op de eerste regeling ${ }^{24}$ ) voor beursgenoteerde vennootschappen een $\mathrm{m} / \mathrm{v}$-quotum (ook wel: ingroeiquotum) voor de samenstelling van de raad van commissarissen (lid 2) dan wel de niet-uitvoerende bestuurders (lid 3). ${ }^{25}$ De regeling is gericht op vennootschappen waarvan aandelen 'zijn toegelaten tot de handel op een gereglementeerde markt als bedoeld in artikel 1:1 van de Wet op het financieel toezicht in Nederland' (lid 1). De reikwijdte van de regeling is opvallend. Ten eerste heeft de regeling een nationale oorsprong (geen implementatie van Europees recht), maar - anders dan hoofdstuk 5.6 van de Wft, art. 2:132 lid 3 BW en de regeling van de wettelijke bedenktijd in art. 2:114b BW, die ook een nationale oorsprong hebben - gaat het alleen om beursnotering aan een RM en niet tevens aan een MTF. Ten tweede gaat de regeling alleen over vennootschappen met een notering aan een $\mathrm{RM}$ in Nederland.

Het voorgestelde art. 2:142b BW bepaalt het volgende. Zolang de raad van commissarissen niet voor ten minste een derde bestaat uit mannen en niet voor ten minste een derde bestaat uit vrouwen, is een benoeming van een persoon tot commissaris

23 Kamerstukken 35628. Vgl. C. de Groot, J. Nijland \& H. Koster, Modernisering NV recht en vergroting diversiteit bestuur en RvC, WPNR 2021, afl. 7320, p. 291-303.

24 Vgl. de voorgestelde art. 2:166 lid 2 en 2:276 lid 2 BW: 'Indien artikel 142b lid 2 of 3 van toepassing is, behoeft voor de raad van commissarissen dan wel de niet-uitvoerende bestuurders geen streefcijfer te worden vastgesteld.'

25 Hierna zal alleen nog over de raad van commissarissen worden gesproken. Vgl. Kamerstukken I 2020/21, 35628, C, p. 6 (MvA): 'De verwachting is dat een meer divers samengestelde raad van commissarissen een positieve doorwerking zal hebben naar de samenstelling van het bestuur van beursvennootschappen. De raad van commissarissen is immers bevoegd ofwel tot benoeming van bestuurders (bij structuurvennootschap) ofwel tot het doen van een voordracht. De voorgestelde maatregelen kunnen bovendien op draagvlak rekenen. In het licht hiervan wordt niet gekozen voor een quotum voor raden van bestuur van beursgenoteerde vennootschappen.' 
nietig, als die benoeming geen bijdrage levert aan een verkleining van het gewenste $\mathrm{m} / \mathrm{v}$-evenwicht (lid 2). In twee gevallen is de benoeming toch rechtsgeldig:

- Er is sprake van een herbenoeming 'binnen acht jaar na het jaar van benoeming'.

- Er is sprake van uitzonderlijke omstandigheden. De regeling verwijst hier naar art. 2:135a lid 5 BW, dat gaat over uitzonderlijke omstandigheden die een afwijking van het beloningsbeleid mogelijk maken: omstandigheden 'waarin de afwijking van het bezoldigingsbeleid noodzakelijk is om de langetermijnbelangen en duurzaamheid van de vennootschap als geheel te dienen of haar levensvatbaarheid te garanderen'. In dit geval geldt de benoeming voor maximaal twee jaar (lid 6).

Lid 2 geeft verder nog aan dat als het aantal leden van de raad van commissarissen niet deelbaar is door drie, voor de een-derdeberekening het hogere getal dat wel deelbaar is door drie leidend is. Bij een raad van commissarissen van vijf leden komt een derde dus uit op twee (een derde van zes). ${ }^{26}$ Een nietige benoeming heeft geen gevolgen voor de rechtsgeldigheid van de besluitvorming van de raad van commissarissen (lid 5), en benoemingen door de Ondernemingskamer in een enquêteprocedure (als onmiddellijke of definitieve voorziening) tellen niet mee (lid 4).

Zowel de streefcijferregeling als de quotumregeling is gekoppeld aan een horizonbepaling: ze vervallen acht jaar na inwerkingtreding van de wet (art. IIA en III van het wetsvoorstel).

\section{Conclusie en kanttekeningen}

In Boek 2 BW komt de term 'beursgenoteerde' nv of bv niet voor. Boek 2 BW heeft het soms over vennootschappen met een beursnotering aan een RM en soms over vennootschappen met een beursnotering aan een RM of een MTF. Ditzelfde onderscheid komt naar voren in de Wft. Regelingen die beperkt zijn tot vennootschappen met een RM-notering hebben een Europeesrechtelijke achtergrond. Regelingen die een nationale achtergrond hebben, gaan verder door zowel vennootschappen met een RM-notering als een MTF-notering onder die regelingen te laten vallen. RM's en MTF's zijn in beginsel alleen handelsplatformen die in de Europese Unie en in de andere EER-landen opereren. De wettelijke bedenktijd en de m/v-quotumregeling (beide hebben een nationale achtergrond) slaan een geheel eigen weg in. De wettelijke bedenktijd heeft een erg ruime reikwijdte: vennootschappen met een beursnotering aan zowel een RM als een MTF, en dat zowel binnen de EU/EER als buiten de EU/EER. De m/v-quotumregeling heeft een erg beperkte reikwijdte: alleen vennootschappen met een beursnotering aan een RM, en dan alleen een RM in Nederland. De wettelijke bedenktijd en de $\mathrm{m} / \mathrm{v}$-quotumregeling roepen verder verschillende uitlegvragen op. commissarissen bestaat uit één persoon.' 
In de regeling van de wettelijke bedenktijd is niet duidelijk hoe de bepaling in art. 2:114b lid 5 BW moet worden uitgelegd die gaat over de mogelijkheid dat het bestuur de bedenktijd meermalen inroept: 'De grond voor het inroepen van de bedenktijd in een van de in lid 2 genoemde gevallen laat de mogelijkheid tot het inroepen van een bedenktijd op een andere grond onverlet.' De vraag die hier rijst, is of art. 2:114b lid 2 BW twee gevallen regelt (onder a en onder b), of drie gevallen regelt: het agenderingsrecht en het bijeenroepingsrecht onder a en een openbaar overnamebod onder $\mathrm{b}$. Het lijkt voor de hand liggend om uit te gaan van drie gevallen, omdat deze drie gevallen een eigen karakter hebben doordat de bedenktijd steeds een eigen beginmoment heeft.

Enkele vragen die de $\mathrm{m} / \mathrm{v}$-quotumregeling oproept, zijn:

- Een herbenoeming die geen bijdrage levert aan een verkleining van het gewenste $\mathrm{m} / \mathrm{v}$-evenwicht (lid 2) is toch mogelijk als sprake is van een herbenoeming 'binnen acht jaar na het jaar van benoeming' (art. 2:142b lid 2 BW). Onduidelijk is of, wanneer iemand in het verleden na een eerste benoeming een of meer keren is herbenoemd, het jaar van benoeming het jaar van de eerste of de laatste benoeming is. Uit de parlementaire geschiedenis komt naar voren dat de eerste benoeming is bedoeld. De memorie van toelichting schrijft dat een herbenoeming mogelijk is 'indien de herbenoeming binnen acht jaar na het jaar van de eerste benoeming heeft plaatsgevonden', en '[h] et ingroeiquotum geldt niet bij herbenoemingen voor zover de herbenoeming van een commissaris binnen acht jaar na het jaar van de eerste benoeming heeft plaatsgevonden'. ${ }^{27}$ Maar deze bedoeling komt niet duidelijk in de wettekst naar voren.

- Op grond van art. 2:142b lid 5 BW heeft een nietige benoeming geen gevolgen voor de rechtsgeldigheid van de besluitvorming van de raad van commissarissen. De parlementaire geschiedenis geeft hier een nadere uitleg aan. In de memorie van toelichting staat: 'Om rechtsonzekerheid te voorkomen, heeft de nietigheid van een benoeming geen gevolgen voor de rechtsgeldigheid van besluiten. Hoewel de benoeming van meet af aan nietig is, zijn mede door de nietig benoemde commissaris genomen besluiten rechtsgeldig tot het moment dat de nietigheid van de benoeming in rechte is vast komen te staan. ${ }^{28}$ In de nota naar aanleiding van het verslag staat in vergelijkbare zin over 'besluiten van de raad van commissarissen die worden genomen nadat de nietigheid van de benoeming in rechte is vast komen te staan': 'Dergelijke besluiten zijn niet rechtsgeldig. ${ }^{.29}$ De parlementaire geschiedenis creëert hier een verschil tussen de rechtsgeldigheid van besluiten die zijn genomen voordat en nadat de rechter een uitspraak heeft gedaan over de nietigheid van een commissarisbenoeming, maar dat verschil komt in de wettekst niet tot uiting.

- In de memorie van toelichting staat over de beloning van een commissaris na een nietige benoeming: 'Nietigheid van de benoeming betekent ook dat de rechtsgrondslag voor de bezoldiging op basis van artikel 145 lid 1 vervalt. De aandeelhouders kunnen tegen de voorgestelde vergoeding stemmen van de op 
nietige wijze benoemde commissaris. ${ }^{30}$ Als er geen rechtsgrondslag is voor de beloning van een commissaris, is de beloning niet verschuldigd. Hier is kennelijk bedoeld dat de aandeelhouders door vóór te stemmen toch akkoord kunnen gaan met de beloning.

30 Kamerstukken II 2020/21, 35628, nr. 3, p. 25 (MvT); vgl. Kamerstukken II 2020/21, 35628, nr. 6, p. $13(\mathrm{NV})$. 